Hundreds of plates of fossils, exquisitely engraved, and maps and sections, too numerous to recount, published for the Geological Survey of Great Britain, amply testify to Mr. Lowry's rare ability as a scientific engraver. Even the familiar card-maps of each town visited year after year by the British Association were invented and produced by Mr. Lowry's skill and ingenuity.

But the days of engraving seem drawing to a close, at least so far as printing from engraved plates is concerned; but the beautiful plates prepared by Mr. Lowry cannot well be surpassed by modern lithography, save in cheapness.

Much as Mr. Lowry's work was valued by scientific men, his amiability of disposition and his modesty won for him even higher esteem among his friends. Many who knew him personally will recall his readiness on all occasions, even at great personal sacrifices, to help those who needed his assistance. His freshness of heart and kindness to young people were marked features in his character. He died on June I 5 .

H. W.

DAVID MOORE, PH.D.

THE death of the Director of the Royal Botanical Gardens at Glasnevin, near Dublin, on June 9 last, has caused a very wide-spread sorrow among the botanists and horticulturists of Europe. Although Dr. Moore had attained the age of seventy-two, yet his physical strength was but little abated, and his mental powers were as strong as they were mature. A peculiarly severe attack of acute cystitis of scarcely four days' duration deprived us of a truly excellent and amiable man.

A native of Dundee, his father, attracted by the fame of Dr. MacKay, the Director of the Botanical Gardens belonging to the University of Dublin, and well known as the author of the "Flora Hibernica," sent David Moore to Dublin to be MacKay's apprentice. The apprentice soon learnt all the master had to teach, and was not long in qualifying himself to form one of the government staff, to whom, under the superintendence of the late General Portlock, was intrusted the Ordnance Survey of Ireland. This was in I834; the Survey began in the County of Londonderry. In $\mathrm{I} \delta 37$ the first volume of its Memoirs was published, to which Moore contributed an essay on the flora of the region surveyed. Shortly after this he was elected by the then Council of the Royal Dublin Society to the charge of their Botanical Gardens at Glasnevin. These gardens are situated within a couple of miles of Dublin, and present a pleasing alternation of flat and gently rising ground, which then slopes to the borders of the little trout stream called the Tolka. They are associated with the memories of Tickell and Swift, and one walk amid old yew trees is "still pointed out as the one much frequented by the Dean when inclined to moody meditation. To enumerate the changes brought about in these Gardens during the forty years' work of Moore, would be to write his and their history. It might almost be said that he found them a mixture of pleasureground and herb-garden; he has left them with all their native loveliness shown off to its very best, and containing for their size one of the best stocked collections in Europe. As the stranger walked there he was told of the literary men who sought for rest and quietness amid their shade; to the list of these sacred memories will now be added the name of a scientific man, whose daily labour for just forty years has resulted in making them known throughout the world. Amidst the practical labours of Moore's life science was not forgotten. He ably assisted MacKay in compiling his list of Irish plants. But he also devoted a great deal of attention to compiling a history of the mosses, liverworts, and algæ of his adopted country, and as the result of his maturer labours in this direction, he published in 1872 an account of the mosses of Ireland, and four years later an account of the Irish Hepaticæ. He, conjointly with A. G. Moore, F.L.S., published an account of the geographical distribution of plants in Ireland, under the title of "Cybele Hibernica." This is scarcely the place to record the numerous "plants introduced by him to our gardens and stores, or to refer to the many interesting new hybrid forms brought into existence through his skill. For such scientific labours he was rewarded by being given the $\mathrm{Ph}$. D. of Leipzig University, and with what we know he regarded as nearly as great an honour, in having the twenty-ninth volume of the third series of the Kew Fournal of Botany dedicated to him by Sir Joseph Hooker, as " to one who, maintaining a very rich and beautiful botanic garden at a high standard of excellence, has advanced botanical science by many original observations and experiments."

Long will the memory of David Moore dwell in the minds of his many friends as that of one true and faithfui, genial and generous.

\section{THE RECENT ERUPTION OF ETNA}

PROF. SILVESTRI has, with most commendable despatch, just issued his report to the Italian Government on the recent eruption of Etna. It takes the form of a quarto pamphlet of nineteen pages, entitled Sulla doppia eruzione dell' Etna scoppiata il 26 Maggio, I879, and it is accompanied by a capital map, showing the exact extent and dimensions of the lava-streams. A reference to the map accompanying the previous article (p. 158) may help the reader to understand more clearly what follows.

At the end of our former article on the subject, we mentioned certain anomalies in the accounts of the eruption already transmitted by telegram from Rome, and at the same time asserted that we must wait for the Government Report before they could be explained. It is satisfactory to find that Prof. Silvestri has completely removed these anomalies, and has given a description of the eruption, which is so connected, reasonable, and precise, that it leaves nothing to be desired.

Silvestri considers that preparations for this eruption have been continued since 1874 , and that this is the fulfilment of the abortive attempt which was then made. On August 29, I874, a rift opened on the north-east side of the mountain, between the great crater and Mojo, and thirty-five small eruptive mouths were formed along its course, together with one larger crateriform monticule, which discharged lava. But after seven hours of activity, the dynamic forces suddenly decreased in intensity, and in two days' time nothing remained of the eruption save a few secondary manifestations. For a fortnight afterwards, however, earthquakes occurred on the north side of the mountain, and the great rift remained open. Silvestri predicted that when the next eruption came this rift would prove the point of least resistance, and that the new lava would flow from it, or from craters raised along its course. This prediction has been completely verified.

The fissure of 1874 has extended itself-on the northnorth-east towards Mojo, on the south-south-west towards Adernò. It is Io kilometres $(6.2$ miles) in length, and passes through the great crater of Etna. On May 26 , the southwestern extremity discharged lava in the direction of Adernò while simultaneously the north-eastern extremity discharged lava in the direction of Mojo, thus presenting the curious anomaly of twin eruptions on opposite sides of the mountain. The craters on the south side of the mountain were situated near the base of Monte Frumento 2,650 metres $(8,743$ feet) above the sea. There were eight eruptive mouths, from 4 to 15 metres in diameter; seven of these were open, while over the eighth was raised a monticule. The lava did not flow directly towards Adernò, I3 kilometres distant, but towards a series of monticules formed during a previous eruption, and known as Monti Grotta degli Archi. It accumulated against the 